\title{
CHONDROID LIPOMA - A RARE LIPOMATOUS TUMOR: A CASE REPORT
}

Idrees Akhtar Afroze ${ }^{1}$, Zakia Abid Sultana²

\section{HOW TO CITE THIS ARTICLE:}

Idrees Akhtar Afroze, Zakia Abid Sultana. "Chondroid Lipoma - A Rare Lipomatous Tumor: A Case Report”. Journal of Evolution of Medical and Dental Sciences 2015; Vol. 4, Issue 62, August 03; Page: 10879-10882,

DOI:10.14260/jemds/2015/1572

ABSTRACT: Chondroid lipoma is a benign tumor with atypical features. It is often confused with myxoid liposarcoma or chondrosarcoma. It's a slow growing tumor and complete excision is recommended.

KEYWORDS: Lipoma, Liposarcoma, Chondrosarcoma.

INTRODUCTION: Lipomatous benign tumors are most common neoplasms. It is a benign neoplasm of mature fat cells. Some variants with atypical features can be of concern like chondroid lipoma which can be confused with myxoid liposarcoma, chondrosarcoma, soft tissue chondroma, myoepithelial lesions. It was first described by Meis and Enzinger in 1993. ${ }^{1}$ Rarely it is a problem to the patient except for cosmetic reasons, for which it has become the subject of interest. As it can easily be misdiagnosed with malignant tumor, a high level of suspicion by pathologist and familiarity with its features are of practical importance to avoid overtreatment and simple excision is curative. ${ }^{2}$

CASE REPORT: A 13 yrs old girl presented to surgery clinic with three yrs. history of mass on right shoulder, slow growing. Physical examination revealed a $3.5 \times 3.0 \times 2.5 \mathrm{~cm}$ mass mobile (Not fixed to under lying structures). X-ray right shoulder showed tumor not attached to under lying bone. Tumor was excised and sent for HPE.

Grossly tumor was well encapsulated and lobulated. Cut surface was oily yellow and smooth.

Microscopically: The tumor is composed of admixture of multivacuolated cells arranged in strands, sheets and nests, together with matures fat cells. Nuclei have regular contour, lack pleomorphism and mitotic activity.

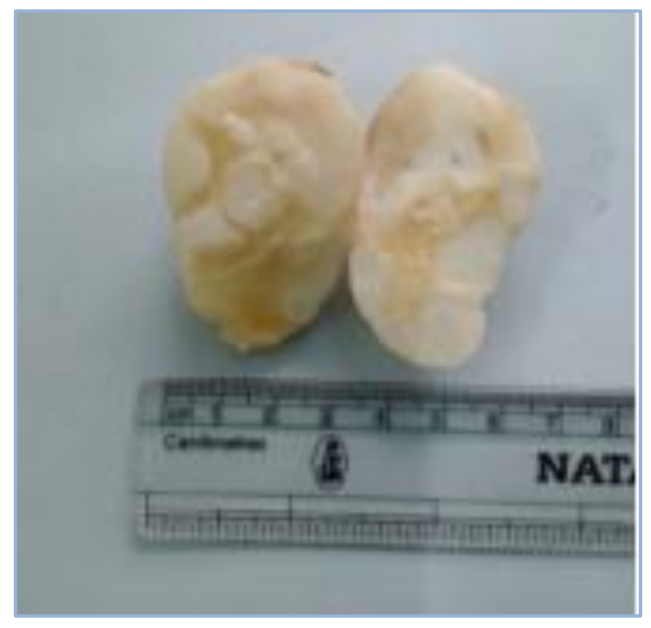

\section{Fig. 1}




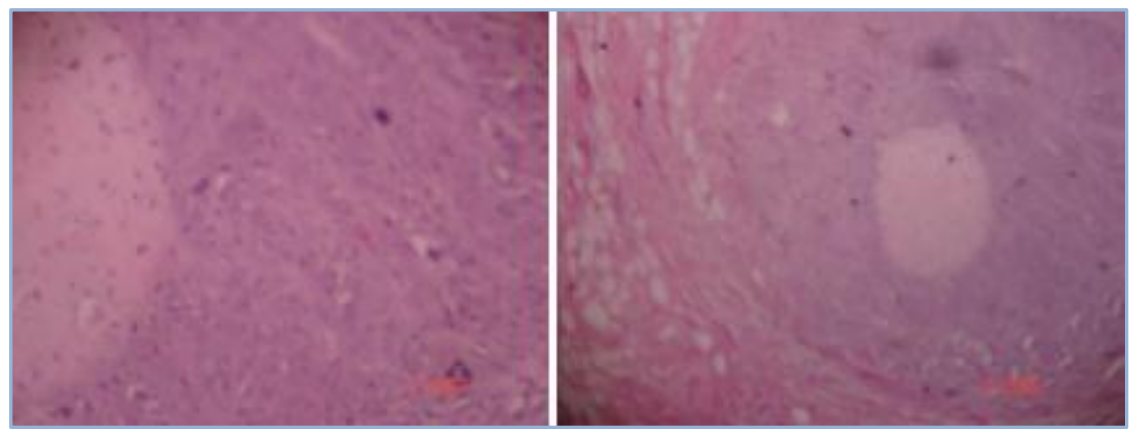

Fig. 2

DISCUSSION: Chondroid lipoma was described as a separate entity in 1993 by Meis and Enzinger. ${ }^{1}$

They reported a series of 20 cases. It has female predilection and is commonly seen between the age group of 14 to 70 yrs. (Median age around 36yrs). ${ }^{1}$ Common sites include the proximal extremities, followed by limb girdles, legs, head and neck region.3,4 They are located mainly subcutaneously.

Grossly chondroid lipoma are well-circumscribed, lobulated, may be encapsulated tumors. They range from $1.5 \mathrm{~cm}$ to $11 \mathrm{~cm}$, but are usually around $4 \mathrm{~cm}$. cut surface is yellow and smooth. ${ }^{5}$

Histologically, the cells are uni or multivacuolated arranged in strands, nest and sheets together with mature adipose tissue. Mostly seen in myxoid and chondroid lipoma. Fibrous strand divide the cells into lobules. The multivacuolated cells show Periodic acid Schiff and Oil Red 0 positivity as they contain glycogen and fat. Cells lack nuclear pleomorphism and mitotic activity. ${ }^{1}$

Ultrastructurally Cells show primitive features to mature features ranging from prelipoblast and chondroblast, to lipoblast and preadpoytes, to mature adipocyte.

Immunohistochemically the tumor cells are positive for S-100, vimentin ad CD68 and some may be positive for keratin. Ki 67 index very low. 3.6

Cytogenetic analysis of chondroid lipoma revealed a balance translocation $t(11,16)$

(q13:p12- 3). This location was earlier detected in hibernoma cases.7,8

Differential diagnosis of chondroid lipoma.

Extra skeletal myxoid chondrosarcoma microscopically shows cord like arrangement of esinophilic cells which are smaller in size than chondroid lipoma. There is absence of mature adipocytes and adipose tissue. ${ }^{9}$ Chondroblast are uniform and show sparse intracytoplasmic vacuoles. Tumor is lobulated and separated by fibrous septa. ${ }^{10}$

Soft tissue chondroma shows multi nucleate giant cells as true hyaline cartilage. It does not contain fat vacuoles. ${ }^{11,12}$ it is located in the soft tissue of hands and feet. In cartilaginous, metaplasia in a lipoma, true cartilage is found. ${ }^{9}$

Chan et al reported "an extraskeletal chondroma with lipoblast like cells" in 1986.13

Myxoid liposarcoma shows areas of mature fat cells mixed with multivacuolated lipoblast with plexiform capillary vasculature.14,15 Cells are uniform and show $\mathrm{t}(12,16)$

Myoepithelial Tumor: Includes cutaneous mixed tumor, and is generally more superficial, has prominent epithelial areas and less of stromal component. Myoepithelial cells have single cytoplasmic vacuolation. 
Parachordoma has trisomy 15, monosomy 1.16.17 and no mature fat cells. Cells are EMA and Keratin positive. 16

\section{REFERENCES:}

1. Meis JM, Enzinger FM. Chondroid lipoma, a unique tumor simulating liposarcoma and myxoid chondrosarcoma. Am J. Surg pathol 1993; 17(11):1103.

2. Thway K, Flora RS, Fischer C. Chondroid lipoma: an update and review. Ann Diag. Pathol 2012; 16(3):230-4.

3. Vasili C, Kligman M, Kirsh G. Incidental finding of chondroid lipoma at total hip arthoplasty. J. South Orthop Assoc 2000; 9(3):219.

4. Lakshmiah SR, Scott KW, Whear NM, Monoghan A. chondroid lipoma: a rare but diagnostically important lesion. Int.J Oral Maxillofac Surg 2000; 29(6):445.

5. Nielsen GP, O" Connell JX, Dichersin GR, Rosenberg AE. Chondroid lipoma, a tumor of white fat cells. A brief report of two cases with ultrastuctural analysis. Am J surg Pathol 1995; 19(11): 1276.

6. Yang Y J, Damron TA, Ambrose JL. Diagnosis of chondroid lipoma by fine needle aspiration biopsy. Arch. Pathol lab Med 2001; 125(9); 1224.

7. Ballaux F, Debiec- rychter M, De Wever, Sciot R. chondroid lipoma is characterized by t(11:16) (q13:p12-13). Virchows Arch 2004; 444(2):208.

8. Thomson TA, Horsman D, Bainbridge TC. Cytogenetics and cytological features of chondroid lipoma of soft tissue. Mod Pathol 1999; 12(1):88.

9. Neilsen GP. Chondroid lipoma. Bone ans soft tissue pathology USCAP virtual slide box http//:www.uscap.org/site-/iap200-/slide18-6v.htm.

10. Enzinger FM, Shraki M. Extraskeletal myxoid chondrosarcoma; an analysis of 34 cases. Hum Pathol 1972; 3:421-425.

11. Chung EB, Enzinge FM. Chondroma of soft parts. Cancer 1978; 41:1414-24.

12. Dahlin DC, Salvador AH. Cartilagenous tumor of soft tissue of Hand and Feet. Mayo clin proc 1974; 49:721-6.

13. Chan JK, lee KC, Saw D. Extraskeletal chondroma with lipoblast like cells. Hum Pathol 1986; 17(12):1285.

14. Enzinger FM, Winston DJ. Liposarcoma, A study of 103 cases. Virchow Arch A Pathol Anat Hostopathol 1962; 335:367-8.

15. Evans HL, Liposarcoma.A study of 55 cases with a reassessment of the classification. Am J Surg Pathol 1979; 3: 507-2.

16. Folpe Al, Agoff SN, Willis J, weiss SW. Parachordoma is immunohistochemically and cytogenetically distinct from axial chordoma and extraskeletal myxoid chondrosarcoma. Am J Surg Pathol 1999; 23(9):1059-67. 


\section{AUTHORS:}

1. Idrees Akhtar Afroze

2. Zakia Abid Sultana

\section{PARTICULARS OF CONTRIBUTORS:}

1. Associate Professor, Department of Pathology, Deccan College of Medical Sciences. Hyderabad.

2. Professor and HOD, Department of Pathology, Deccan College of Medical Sciences. Hyderabad.

FINANCIAL OR OTHER COMPETING INTERESTS: None

\section{NAME ADDRESS EMAIL ID OF THE} CORRESPONDING AUTHOR:

Dr. Idrees Akhtar Afroze,

Deccan College of Medical Sciences, DMRL X Road,

Santosh Nagar, Kanchanbagh,

Hyderabad-500058, T. S.

E-mail: dearidrees@rediffmail.com

Date of Submission: 01/07/2015.

Date of Peer Review: 02/07/2015.

Date of Acceptance: 27/07/2015.

Date of Publishing: 03/08/2015. 